\title{
Updated distribution of Aedes albopictus (Diptera: Culicidae) in Spain: new findings in the mainland Spanish Levante, 2013
}

\author{
Pedro María Alarcón-Elbal'1/+ ${ }^{+}$, Sarah Delacour Estrella1, Ignacio Ruiz Arrondo', Francisco Collantes ${ }^{2}$, \\ Juan Antonio Delgado Iniesta², José Morales-Bueno ${ }^{3}$, Pedro Francisco Sánchez-López ${ }^{4}$, \\ Carmen Amela ${ }^{5}$, María José Sierra-Moros ${ }^{5}$, Ricardo Molina ${ }^{6}$, Javier Lucientes ${ }^{1}$
}

\begin{abstract}
${ }^{1}$ Departamento de Patología Animal, Facultad de Veterinaria, Universidad de Zaragoza, Zaragoza, Spain ${ }^{2}$ Departamento de Zoología y Antropología Física, Facultad de Biología, Universidad de Murcia, Murcia, Spain ${ }^{3}$ Rafaela Belmonte Nortes, Murcia, Spain ${ }^{4}$ Servicio de Sanidad Ambiental, Dirección General de Salud Pública, Consejería de Sanidad y Política Social de la Región de Murcia, Spain ${ }^{5}$ Centro de Coordinación de Alertas y Emergencias Sanitarias, Dirección General de Salud Pública, Calidad e Innovación, Ministerio de Sanidad, Servicios Sociales e Igualdad, Madrid, Spain ${ }^{6}$ Unidad de Entomología Médica, Servicio de Parasitología, Centro Nacional de Microbiología, Instituto de Salud Carlos III, Madrid, Spain
\end{abstract}

In 2004, Aedes (Stegomyia) albopictus (Skuse, 1894) was observed for the first time in Catalonia, northeastern Spain. A decade later, it has spread throughout the eastern Mediterranean region of the country and the Balearic Islands. Framed within a national surveillance project, we present the results of monitoring in 2013 in the autonomous communities of the mainland Levante. The current study reveals a remarkable increase in the spread of the invasive mosquito in relation to results from 2012; the species was present and well-established in 48 municipalities, most of which were along the Mediterranean coastline from the Valencian Community to the Region of Murcia.

Key words: Aedes albopictus - entomological surveillance - ovitrap - false negative - Spanish Mediterranean coast

The Asian tiger mosquito, Aedes (Stegomyia) albopictus (Skuse, 1894), is one of the 100 most invasive species, according to the Global Invasive Species Database (Lowe et al. 2000). This species originated in Asia, but it has spread worldwide over the past few decades via human travel and international commerce. It was introduced to Europe through Albania in 1979 (Adhami \& Reiter 1998) and, 35 years later, the mosquito is well-established in 18 European countries and two city-states (Šebesta et al. 2012).

In addition to being a biting nuisance, this mosquito is an important vector of several viruses, such as chikungunya and dengue (Gratz 2004). In fact, it has been responsible for the recent autochthonous chikungunya and dengue outbreaks in Europe (Angelini et al. 2007, La Ruche et al. 2010, Gjenero-Margan et al. 2011, Marchand et al. 2013).

In Spain, this species has colonised the majority of the coastal Mediterranean region since its arrival in 2004 (Aranda et al. 2006). At present, the mosquito is established and widespread in the provinces of Gerona, Barcelona and Tarragona (Catalonia) (Torrell-Sorio \& Fernández-Rodríguez 2008), Castellón (Delacour-Estrella et al. 2010) and Alicante (Roiz et al. 2007) (Valencian

\footnotetext{
doi: $10.1590 / 0074-0276140214$

Financial support: Directorate General of Public Health, Quality and Innovation, Ministry of Health, Social Services and Equity in Spain (Entomological surveillance at airports and ports against imported vectors of exotic infectious diseases and surveillance of potential indigenous vectors of such diseases project, OTRI 2013/0215)

+ Corresponding author: pedro.alarcon@uv.es

Received 11 June 2014

Accepted 4 August 2014
}

Community). Besides, it is less widespread in Valencia (Alarcón-Elbal et al. 2013), the Region of Murcia (Collantes \& Delgado 2011) and the Balearic Islands (Miquel et al. 2013). Moreover, it is threatening to colonise the region of Andalusia (including the Atlantic watershed) and the Basque Country (EID Atlantique 2014). Additionally, the risk of spread from Spain to Portugal cannot be ignored, given that the Iberian Peninsula forms a single geographical unit.

In this study, we present results for Ae. albopictus from the national surveillance project against imported vectors.

\section{MATERIALS AND METHODS}

The study areas comprised the coastal part of the autonomous regions of Valencia and Murcia, which are both located in the Mediterranean basin. To monitor the presence of Ae. albopictus, we used traditional oviposition traps, also known as ovitraps (Fay \& Eliason 1966), which are the preferred tool for environmental surveillance of Aedes activity (Becker et al. 2003). These traps include a dark container filled with water and a wooden paddle that serves as an oviposition substrate; an insect growth regulator was also added to effectively control breeding.

Traps were placed around optimum breeding sites where habitats suitable for expansion were identified. A special emphasis was placed on anthropic environments, such as cemeteries, petrol stations, residential complexes with gardens, urban parks and gardened roundabouts. Because only a subset of the municipalities could be sampled due to budgetary restrictions, their location with respect to the coast was an important selection criterion. As in other regions (Giménez et al. 2007), a significant number of the new locations in Valencia (which later tested positive for Ae. albopictus) were chosen based on complaints of discomfort due to mosquito bites. 
A total of 1,212 ovitraps were placed during the study period. The studied municipalities (Fig. 1) included Castellón (23 municipalities, $17 \%$ of the total area, $23.1 \%$ of the provincial surface and $91.5 \%$ of the coastline), Valencia ( 15 municipalities, $4.9 \%, 6.9 \%$ and $86 \%$ ), Alicante (24 municipalities, 17\%, 26.6\% and 39.8\%) and Murcia (13 municipalities, $28.9 \%, 37.5 \%$ and $100 \%$ ).

The traps were operational from the beginning of September to the middle of November of 2013 and some of the traps continued to work until the end of the year. This sampling period included the months with the highest recorded densities in Spain (Lucientes-Curdi et al. 2014). The wooden paddles and water were replaced every two weeks and transported in closed containers to the laboratory. The paddles were then studied under a stereoscope and the eggs found were introduced to water to facilitate hatching, following the method described by Alarcón-Elbal et al. (2010). The species were then classified using the taxonomic key of Schaffner et al. (2001).

\section{RESULTS AND DISCUSSION}

Seventy-five municipalities were sampled and 48 of them tested positive for the presence of Asian tiger mosquito eggs; these results indicated $65 \%$ positivity for all locations studied (Fig. 2). It must be emphasised that not all municipalities were sampled with equal effort; therefore, a distinction was made between negative results in areas that were sparsely sampled and negative results from thoroughly sampled municipalities.

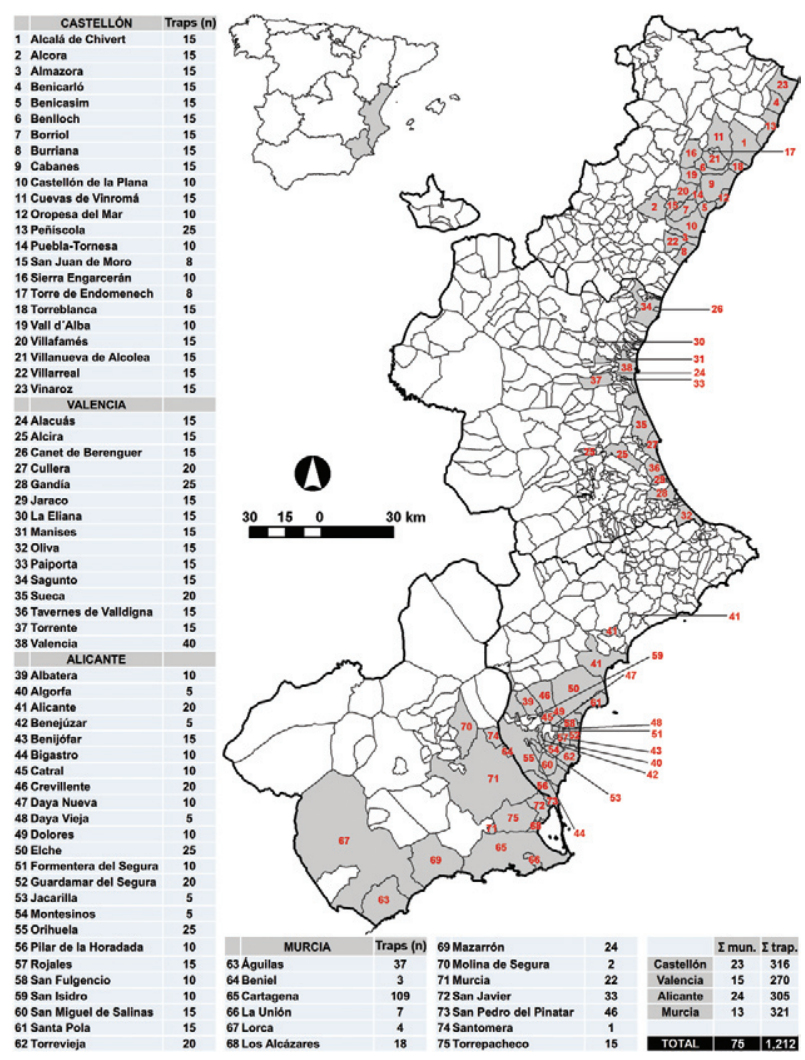

Fig. 1: map and table of sampled municipalities showing the number of placed ovitraps in every municipality.

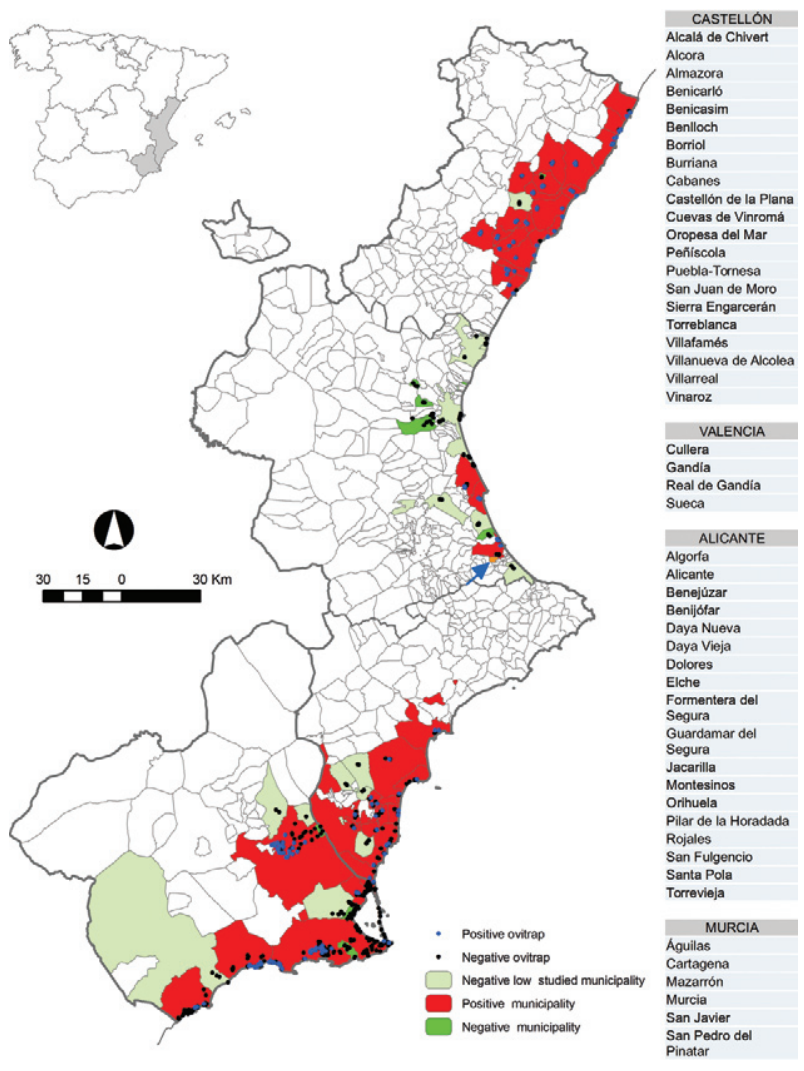

Fig. 2: map of sampled municipalities showing positive and negatives ones for Aedes albopictus presence. Table of positive municipalities. The municipality of Real de Gandía (blue arrow) is coloured as positive following Bueno-Marí et al. (2013).

Ae. albopictus has spread through the province of Castellón along the coast northward and southward since it was first detected in 2010 in Benicasim (Delacour-Estrella et al. 2010). The vector's spread to inland villages was observed in 2012 (Lucientes-Curdi et al. 2014) and confirmed by the current results, which indicate that 21 of the 23 sampled municipalities were positive (91.3\%).

Ae. albopictus was first detected in the province of Valencia in 2013, thereby completing the Mediterranean provincial corridor (Alarcón-Elbal et al. 2013). The findings of that study indicated that three of the 15 sampled municipalities were positive $(20 \%)$, as was Real de Gandía (Bueno-Marí et al. 2013).

The mosquito was first detected in the province of Alicante in 2005 (Roiz et al. 2007). These first Aedes populations outside Catalonia could have been transported there by a private car from Sant Cugat del Vallés, in Barcelona, that was driven to Orihuela by a resident of Catalonia who had a holiday house in this municipality (Lucientes-Curdi et al. 2014). It was later found in abundance in Torrevieja in 2009 (Delacour et al. 2009, Bueno-Marí et al. 2010) and, at present, it has been detected in 18 of the 24 sampled municipalities $(75 \%)$.

In the Region of Murcia, the dipteran was first detected in 2011 near the city of Murcia (Collantes \& Delgado 2011). The current results indicate that six of the 13 sampled municipalities were positive (46.2\%). How- 
ever, although Collantes et al. (2014) observed the first outdoor winter reproductive activity of Ae. albopictus in Europe during the winter of 2012-2013 in Murcia, this behaviour was only observed in the city of Cartagena during the past winter.

In summary, one province and 30 new municipalities were added to the list of areas affected by Ae. albopictus in the mainland Spanish Levante in 2013 (Fig. 3).

Over the past decade, entomological studies focused on the search for new populations revealed that two different processes have been intertwined, making difficult to reconstruct the true sequence of occupation. The mosquito expanded along over $650 \mathrm{~km}$ of the Mediterranean coast in 10 years and this wide expansion was most likely propelled by transport of the mosquito via ground vehicles. The transportation of adults in cars and trucks was documented previously and data indicate that the number of mosquitoes transported correlates with the traffic volume (Flacio et al. 2006).

On the one hand, as in other countries [e.g., Italy, see review map, figure 4, in Otranto et al. (2013)], Ae. albopictus has dispersed and colonised following jumping and patch patterns, respectively. On the other hand, scientific research on its movement has been irregular due to budgetary limits. For example, the Asian tiger mosquito was discovered near Murcia city in 2011 and individuals, who were already familiar with Ae. albopictus because they lived in Catalonia, informed entomologists of its possible presence in Mazarrón municipality in November of the same year. However, we were unable to verify its presence immediately and Ae. albopictus was confirmed in Mazarrón by Bueno-Marí et al. (2012) the following summer.

As noted before, certain free municipalities may be understudied. We may therefore be obtaining false negative results from these municipalities, as in the case of Lorca municipality (Murcia province). There, only four traps were placed within a small coastal part of its territory. However, positive traps were observed in the nearby municipalities of Mazarrón and Águilas, which are located on both sides of the coastline (Fig. 2). The European Centre for Disease Prevention and Control guidelines (ECDC 2012) recommend a high density of ovitraps; however, they were not available due to limits in the budget allocated for surveillance. As a result, it was necessary to reduce the effort.

Nevertheless, the inconsistent arrangement of ovitraps allowed us to obtain evidence of possible false negatives in certain municipalities. In the San Pedro del Pinatar municipality (Murcia), traps were placed in two distinct arrangements: one trap per point at 16 points and five traps per point at two points. All points with single traps were negative, whereas the five-trap points were positive. However, not all traps at the same location were positive at the same time. Similar findings were observed in San Javier, the closer municipality to San Pedro del Pinatar.

Ovitraps are widely used because they are cheaper than other sampling methods, both in terms of materials and personnel and because they are superior to larval sampling to detect positive areas of Ae. albopictus (Azevedo-Marques et al. 1993), but some studies have revealed that ovitraps underestimate the population of this mosquito (Kröckel et al. 2006, Fonseca et al. 2012, Becker et al. 2013).

Previous studies point to the behaviour of the females as a possible source of the false negatives. It has been demonstrated that female Ae. albopictus scatter their eggs during each gonotrophic cycle (Rozeboom et al. 1973). Additionally, other studies revealed that females prefer to lay their eggs in pristine containers, avoiding the presence of co-specific eggs; it therefore follows that if there are many abandoned containers, the females have more potential breeding sites from which to choose (Fonseca et al. 2012). Due to this behaviour and despite the positive correlation between the number of eggs in ovitraps and the number of females caught using another type of trap (Carrieri et al. 2011), the number of eggs is not a good

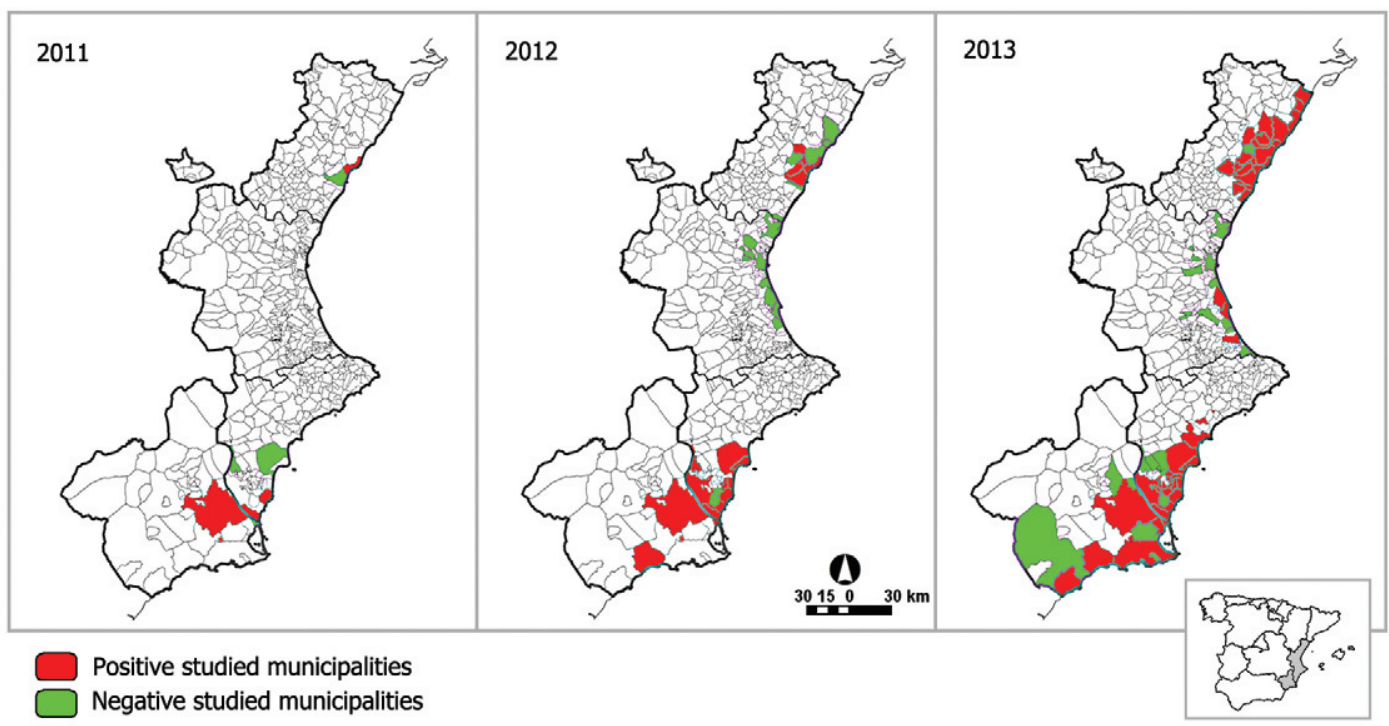

Fig. 3: comparative sampling maps 2011-2013 for Aedes albopictus in the Spanish Levante. 
metric to estimate the number of females visiting the ovitrap (Facchinelli et al. 2007) and, thus, the population of Ae. albopictus. Additionally, Facchinelli et al. (2007) observed that in areas with low densities of Asian tiger mosquito, the theoretical minimum number of ovitraps needed to detect the dipteran was presumably quite high even with low levels of precision. Similarly, Collantes et al. (2014) pointed out that in the Spanish Levante, due to our "water culture", people arrange containers for collecting rainwater and saving water in pots. This practice ensures that a steady water supply is available for the reproductive cycle of Ae. albopictus even in the absence of significant rainfall. Given the combined circumstances of low densities of Ae. albopictus, low densities of ovitraps and high densities of containers, whether abandoned or intentionally arranged, false negatives are likely.

For these reasons, even a low level of positive results is alarming news. In parallel with the events following Romi's (2001) warning regarding possible epidemics related to Ae. albopictus and their occurrence in 2007 (Angelini et al. 2007), the presence of the Asian tiger mosquito in Spain remains a health problem that is underestimated by local health authorities. However, in Catalonia (Curcó et al. 2008) and municipalities within the Spanish Levante that are moderately to severely affected (unpublished observations), citizens are acutely aware of the problem.

In conclusion, we want to emphasise that the most productive mosquito control techniques for Ae. albopictus are sanitation and breeding source reduction, efforts that necessarily require the involvement of state governments and the cooperation, diligence and help of the general public. In this respect, dwindling budgetary allocations to the health sector are a great concern with respect to the threat of vectors and vector-borne diseases.

\section{ACKNOWLEDGEMENTS}

To the Compañía de Tratamientos de Levante SL, for their support in the sampling work, and to Matilde Pérez-García, for the revision on English writing and style.

\section{REFERENCES}

Adhami J, Reiter P 1998. Introduction and establishment of Aedes (Stegomyia) albopictus Skuse (Diptera: Culicidae) in Albania. $J$ Am Mosq Control Assoc 14: 340-343.

Alarcón-Elbal PM, Delacour S, Pinal R, Ruiz-Arrondo I, Muñoz A, Bengoa M, Eritja R, Lucientes J 2010. Establecimiento y mantenimiento de una colonia autóctona española de Aedes (Stegomyia) albopictus Skuse, 1894, (Diptera, Culicidae) en laboratorio. Rev Ibero-Latinoam Parasitol 69: 140-148.

Alarcón-Elbal PM, Delacour-Estrella S, Collantes F, Delgado JA, Ruiz-Arrondo I, Pinal-Prieto R, Melero-Alcíbar R, Molina R, Sierra MJ, Amela C, Lucientes J 2013. Primeros hallazgos de Aedes (Stegomyia) albopictus (Skuse, 1894) en la provincia de Valencia, España. An Biol 35: 95-99.

Angelini R, Finarelli AC, Angelini P, Po C, Petropulacos K, Macini P, Fiorentini C, Fortuna C, Venturi G, Romi R, Majori G, Nicoletti L, Rezza G, Cassone A 2007. An outbreak of chikungunya fever in the province of Ravenna, Italy. Euro Surveill 12: 3260.

Aranda C, Eritja R, Roiz D 2006. First record and establishment of the mosquito Aedes albopictus in Spain. Med Vet Entomol 20: $150-152$
Azevedo-Marques CC, Monteiro-Marques GRA, Brito M, Neto LGS, Ishibashi VC, Gomes FA 1993. Estudo comparativo de eficácia de larvitrampas e ovitrampas para vigilância de vetores de dengue e febre amarela. Rev Saude Publica 27: 237-241.

Becker N, Geier M, Balczun C, Bradersen U, Huber K, Kiel E, Krüger A, Lühken R, Orendt C, Plenge-Bönig A, Rose A, Schaub GA, Tannich E 2013. Repeated introduction of Aedes albopictus into Germany, July to October 2012. Parasitol Res 112: 1787-1790.

Becker N, Petric D, Zgomba M, Boase C, Dahl C, Lane J, Kaiser A 2003. Mosquitoes and their control, Kluwer Academic/Plenum Publishers, New York, 498 pp.

Bueno-Marí R, Bernués-Bañeres A, Muñoz-Rodríguez M, JiménezPeydró R 2013. Primera cita de Aedes albopictus (Skuse, 1894) en la provincia de Valencia (Diptera, Culicidae). Boln Asoc esp Ent 37: 375-378.

Bueno-Marí R, Chordá-Olmos FA, Bernués-Bañeres A, JiménezPeydró R 2010. Detección de Aedes albopictus (Skuse, 1894) en Torrevieja (Alicante, España). Boln Asoc esp Ent 33: 529-532.

Bueno-Marí R, García-Mújica P, Rico-Miralles J, Agulló-Ronco A 2012. Nuevos datos sobre el proceso de expansión de Aedes albopictus (Skuse, 1894) (Diptera, Culicidae) por el sureste de la Península Ibérica: hallazgo de la especie en Mazarrón (Murcia, España). Bol SEA 51: 307-309.

Carrieri M, Angelini P, Venturelli C, Maccagnani B, Bellini R 2011. Aedes albopictus (Diptera: Culicidae) population size survey in the 2007 chikungunya outbreak area in Italy. I. Characterization of breeding sites and evaluation of sampling methodologies. $J$ Med Entomol 48: 1214-1225.

Collantes F, Delgado JA 2011. Primera cita de Aedes (Stegomyia) albopictus (Skuse, 1894) en la Región de Murcia. An Biol 33: 99-101.

Collantes F, Delgado JA, Alarcón-Elbal PM, Delacour S, Lucientes J 2014. First confirmed outdoor winter reproductive activity of Asian tiger mosquito (Aedes albopictus) in Europe. An Biol 36: 71-76.

Curcó N, Giménez N, Serra M, Ripoll A, García M, Vivesa P 2008. Asian tiger mosquito bites: perception of the affected population after Aedes albopictus became established in Spain. Actas Dermosifiliogr 99: 708-713.

Delacour S, Alarcón-Elbal P, Bengoa M, Melero-Alcíbar R, Pinal R, Ruiz-Arrondo I, Molina R, Lucientes J 2009. Aedes (Stegomyia) albopictus (Skuse, 1894) primera cita en Torrevieja (Alicante). Bol SEA 45: 518.

Delacour-Estrella S, Bravo-Minguet D, Alarcón-Elbal PM, Bengoa M, Casanova A, Melero-Alcibar R, Pinal R, Ruiz-Arrondo I, Molina R, Lucientes J 2010. Detección de Aedes (Stegomyia) albopictus (Skuse, 1894) (Diptera: Culicidae) en Benicàssim. Primera cita para la provincia de Castellón (España). Bol SEA 47: 440.

ECDC - European Centre for Disease Prevention and Control 2012. Guidelines for the surveillance of invasive mosquitoes in Europe. Stockholm: ECDC Technical Report. Available from: ecdc.europa.eu/en/publications/Publications/TER-Mosquito-surveillanceguidelines.pdf.

EID Atlantique - Établissement Public Interdépartemental Pour la Démoustication du Littoral Atlantique 2014. Rapport annuel 2013. Available from: eidatlantique.dtspro.fr/ipc/librairies/fichierVisualisation asp?CodeLibrairie $=79634 \&$ CodeFichier $=1019552$.

Facchinelli L, Valerio L, Pombi M, Reiter P, Costantini C, Della Torre A 2007. Development of a novel sticky trap for container-breeding mosquitoes and evaluation of its sampling properties to monitor urban populations of Aedes albopictus. Med Vet Entomol 21: 183-195.

Fay RW, Eliason DA 1966. A preferred oviposition site as a surveillance method for Aedes aegypti. Mosq News 26: 531-535. 
Flacio E, Lüthy P, Patocchi N, Peduzzi R, Guidotti F, Radczuweit S 2006. Bericht 2006 zur überwachung und bekämpfung der asiatischen Tigermücke, Aedes albopictus, im Kanton Tessin. Jahresbericht 2006 Gruppo lavoro zanzare, Divisione della Salute Publica, Bellinzona, p. 1-10.

Fonseca DM, Unlu I, Crepeau T, Farajollahi A, Healy SP, Bartlett-Healy K, Strickman D, Gaugler R, Hamilton G, Klinee D, Clark GG 2012. Area-wide management of Aedes albopictus. Part 2: gauging the efficacy of traditional integrated pest control measures against urban container mosquitoes. Pest Manag Sci 67: 965-974.

Giménez N, Barahona M, Casasa A, Domingo A, Gavagnach M, Martí C 2007. Llegada de Aedes albopictus a España: un nuevo reto para la salud pública. Gac Sanit 21: 25-28.

Gjenero-Margan I, Aleraj B, Krajcar D, Lesnikar V, Klobučar A, PemNovosel I, Kurečić-Filipović S, Komparak S, Martić R, Duričić S, Betica-Radić L, Okmadžić J, Vilibić-Čavlek T, Babić-Erceg A, Turković B, Avsić-Županc T, Radić I, Ljubić M, Sarac K, Benić N, Mlinarić-Galinović G 2011. Autochthonous dengue fever in Croatia, August-September 2010. Euro Surveill 16: 19805.

Gratz NG 2004. Critical review of the vector status of Aedes albopictus. Med Vet Entomol 18: 215-227.

Kröckel U, Rose A, Eiras Ae, Geier M 2006. New tools for surveillance of adult yellow fever mosquitoes: comparison of trap catches with human landing rates in an urban environment. J Am Mosq Control Assoc 22: 229-238.

La Ruche G, Souarès Y, Armengaud A, Peloux-Petiot F, Delaunay P, Desprès $\mathrm{P}$, Lenglet A, Jourdain F, Leparc-Goffart I, Charlet F, Ollier L, Mantey K, Mollet T, Fournier JP, Torrents R, Leitmeyer K, Hilairet P, Zeller H, Van Bortel W, Dejour-Salamanca D, Grandadam M, Gastellu-Etchegorry M 2010. First two autochthonous dengue virus infections in metropolitan France, September 2010. Euro Surveill 15: 19676.

Lowe S, Browne M, Boudjelas S, de Poorter M 2000. 100 of the world's worst invasive alien species: a selection from the Global Invasive Species Database, IUCN/SSC Invasive Species Specialist Group, Auckland, 12 pp.
Lucientes-Curdi J, Molina-Moreno R, Amela-Heras C, Simon-Soria F, Santos-Sanz S, Sánchez-Gómez A, Suárez-Rodriguez B, Sierra-Moros MJ 2014. Dispersion of Aedes albopictus in the Spanish Mediterranean area. Eur J Public Health 24: 637-640.

Marchand E, Prat C, Jeannin C, Lafont E, Bergmann T, Flusin O, Rizzi J, Roux N, Busso V, Deniau J, Noel H, Vaillant V, LeparcGoffart I, Six C, Paty MC 2013. Autochthonous case of dengue in France, October 2013. Euro Surveill 18: 20661.

Miquel M, del Río R, Borràs D, Barceló C, Paredes-Esquivel C, Lucientes J, Miranda MA 2013. First detection of Aedes albopictus (Diptera: Culicidae) in the Balearic Islands (Spain) and assessment of its establishment according to the ECDC guidelines. $J$ European Mosq Control Assoc 31: 8-11.

Otranto D, Dantas-Torres F, Brianti E, Traversa D, Petrić D, Genchi C, Capelli G 2013. Vector-borne helminths of dogs and humans in Europe. Parasit Vectors 6: 16.

Roiz D, Eritja R, Alcíbar RM, Molina R, Marquès E, Ruiz S, Escosa R, Aranda C, Lucientes J 2007. Distribución de Aedes (Stegomyia) albopictus (Skuse, 1894) (Diptera, Culicidae) en España. Bol SEA 40: 523-526.

Romi R 2001. Aedes albopictus in Italia: un problema sanitario sottovalutato. Ann Ist Super Sanita 37: 241-247.

Rozeboom LE, Rosen L, Ikeda J 1973. Observations on oviposition by Aedes (S.) albopictus Skuse and Ae. (S.) polynesiensis Marks in nature. J Med Entomol 10: 397-399.

Schaffner F, Angel G, Geoffreoy B, Hervy JP, Rhaiem A, Brunhes J 2001. The mosquitoes of Europe/Les moustiques d'Europe [CDROM]. IRD Éditions y EID Méditerranée, Montpellier.

Šebesta O, Rudolf I, Betášová L, Peško J, Hubálek Z 2012. An invasive mosquito species Aedes albopictus found in the Czech Republic, 2012. Euro Surveill 17: 20301.

Torrell-Sorio A, Fernández-Rodríguez J 2008. Caracterització de la població del mosquit tigre asiàtic (Aedes albopictus) a Catalunya 2008, Direcció General del Medi Natural/Generalitat de Catalunya, Barcelona, $68 \mathrm{pp}$. 